\title{
Ekonomi Kreatif Berbasis Budaya Lokal
}

\section{Fitria}

Sekolah Tinggi Ekonomi Islam (STEI) Al-Furqon Prabumulih

E-mail : Fitriafitri781@gmail.com

\begin{abstract}
This community service activity discusses talent development in the creative economy. Seen in terms of potential, in terms of opportunities and ways that can be taken to be able to develop a creative economy based on local culture. The purpose of this community service is to foster the curiosity of the students of SMK Muhammadiyah 4 Palembang in the creative economy. In today's digital era, where there are lots of opportunities for millennial children to channel their talents, such as being a YouTuber or entrepreneurship through online. With this community service, it is hoped that it will be able to provide an understanding to students that there are many things that can be done in this era, which can even increase their own income and more than that can help the economy of the family and the surrounding community.
\end{abstract}

\section{Keywords: Creative Economy}

\begin{abstract}
Abstrak
Kegiatan pengabdian masyarakat ini membahas tentang pengembangan bakat di bidang ekonomi kreatif. Dilihat dai segi potensi, dari segi peluang serta cara-cara yang bisa ditempuh untuk dapat mengembangkan ekonomi kreatif berbasis budaya lokal. Tujuan dari pengabdian kepada masyarakat ini adalah menumbuhkan rasa keingintahuan siswa siswi SMK Muhammadiyah 4 Palembang di bidang ekonomi kreatif. Di era digital saat ini, dimana banyak sekali peluang bagi anak-anak milenial menyalurkan bakatnya seperti menjadi Youtober atau dengan berwirausaha melalui online. Dengan adanya pengabdian kepada masyarakat ini diharapkan mampu memberikan pemahaman kepada para siswa siswi bahwa banyak hal yang bisa dilakukan di era sekarang ini, yang bahkan dapat meningkatkan pendapatan mereka sendiri dan lebih dari itu dapat membantu perekonomian keluarga serta masyarakat sekitar.
\end{abstract}

Kata Kunci: Ekonomi Kreatif

\section{Pendahuluan}

Ekonomi kreatif adalah pemanfaatan cadangan sumber daya yang bukan hanya terbarukan, bahkan tak terbatas, ide, gagasam, bakat atau talenta dan kreativitas. Nilai ekonomi dari suatu produk atau jasa di era kreatif tidak lagi ditentukan oleh bahan baku atau system produksi seperti pada era industry, tetapi lebih kepada pemanfaatan kreativitas dan penciptaan perkembangan teknologi yang semakin maju. Industry tidak dapat lagi bersaing di pasar global dengan 
hanya mengandalkan harga atau kualitas produk saja, tetapi harus bersaing berbasis inovasi, kreativitas dan imajinasi (Rochmat Adly Purnomo, 2016).

Pada saat ini bisnis di bidang kreativitas sangat antusias dilakukan oleh para masyarakat. Dan sangat pesat dan kompetisi bisnis pada sector mikro kecil dan menengah cukup ketat, ketatnya persaingan bisnis pada level skala kecil mendorong para pelaku usaha untuk lebih kreatif dalam menyikapinya. Kualitas pelayanan juga harus memiliki keunggulan dan daya tarik tersendiri sebagai identitas suatu bisnis yang dapat dikenal oleh masyarakat secara luas.

Palembang merupakan salah satu kota yang mengembangkan ekonomi kreatif ini terbukti dengan dijadikannya Palembang sebagai kota kreatif pada tahun 2019 dari subsector kuliner. Saat ini sudah ada 4000 UMKM yang mendapatkan bantuan dari pemerintah Palembang. Pemerintah kota Palembang sangat mendukung gerakan ekonomi kreatif, gabungan antra Akademisi, bisnis, komunitas, pemeintah, dan media (ABCG-M) dibentuk agar dapat mengatasi permasalahan yang akan menghambat pengembangan ekonomi kreatif. Selain itu pemerintah kota Palembang terus berupaya menambah dan mengembangkan ruang public seperti pemanfaatan jalan sudirman dan jalan kenten untuk para komunitas agar dapat berinteraksi dan berinovasi dengan kreativitas yang dimiliki (pemkot pemerintah Palembang, 2016).

Fakta di atas membuktikan bahwa dukungan pemerintah sangatlah besar untuk menumbuhkan para generasi ke generasi untuk meningkatkan ekonomi kreatif. Salah satu nya adalah sekolah Menengah kejuruan 04 Muhammadiyah Palembang. SMK 4 Muhammadiyah adalah salah satu sekolah yang mengembangkan ekonomi kreatif dengan cara memberikan edukasi tentang bagaimana pentingnya membuat kreativitas yang nantinya bisa mempunyai nilai tambah tentunya juga bermanfaat bagi dirinya dan orang sekitarnya. Namun mereka belum memiliki motivasi yang tinggi untuk mengembangkan ide-ide kreatif tersebut serta masih rendahnya akses terhadap informasi, teknologi, pelatihan-pelatihan keterampilan serta jaringan pemasaran hasil usahanya. Untuk itu perlu dilakukan penyuluhan terutama kepada untuk menambah pengetahuan mengenai bagaimana mengembangkan ide-ide kreatif menjadi sumber-sumber ekonomi kreatif yang dapat meningkatkan pendapatan dan kesejahteraan masyarakat.

\section{Metode Pengabdian}

1. Metode Pengabdian

Rangkaian kegiatan pengabdian masyarakat adalah sebagai berikut

a. Bentuk pengabdian

Bentuk kegiatan yang dilakukan dalam sosialisasi adalah

1) Pemaparan materi tentang ekonomi kreatif

2) Pemahaman dan Tanya jawab tentang ekonomi kreatif

b. Tempat kegiatan

Adapun tempat kegiatan atau lokasi kegiatan dilaksanakan di SMK Muhammadiyah 4 Palembang

c. Proses kegiatan

Adapun proses kegiatan dilaksanakan dalam waktu 1 hari pada hari kamis tanggal 26 september 2019 . adapun kegiatan yang dilakukan selama kegiatan berlangsung adalah sebagai berikut :

1) Registrasi peserta

2) Penyampaian materi tentang mengapa ekonomi kreatif penting. 
3) Ekonomi kreatif berbasis budaya lokal

4) Tanya jawab mengenai ekonomi kreatif

5) Penutup dan doa

2. Waktu kegiatan dan materi pokok dalam kegiatan

Pelaksanaan kegiatan dilakukan dalam waktu satu hari pada hari kamis. Adapun jadwal pelaksanaannya adalah sebagai berikut :

\begin{tabular}{|l|l|l|}
\hline Waktu & Materi & Narasumber \\
\hline $09.00-10.00$ & Registrasi Peserta & Siswa siswi \\
\hline 10.11 .00 & $\begin{array}{l}\text { Materi ruang lingkung } \\
\text { ekonomi kreatif }\end{array}$ & Fitria, M.E \\
\hline $11.00-11.30$ & $\begin{array}{l}\text { Pentingnya ekonomi } \\
\text { kreatif }\end{array}$ & Fitria, M.E \\
\hline $12.00-13.00$ & $\begin{array}{l}\text { ISOMA } \\
\text { Ekonomi Kreatif berbasis } \\
\text { budaya lokal }\end{array}$ & Fitria, M.E \\
\hline $13.00-14.00$ & Tanya jawab & Fitria, M.E \\
\hline $15.00-15.30$ & Penutup dan doa & Rika Rahmadina Putri \\
\hline
\end{tabular}

\section{Tinjauan Pustaka}

\section{Pengertian Ekonomi Kreatif}

Beberapa definisi dan batasan industri kratif menurut para ahli :

a. $\quad$ Menurut Departemen Perdagangan RI (2009:5)

"Industri kreatif adalah industri yang berasala dari pemanfaatan kreativitas, keterampilan serta bakat individu untuk menciptakan kesejahteraan dan lapangan pekerjaan dengan menghasilkan dan memberdayakan daya kreasi dan daya cipta individu tersebut."

b. Menurut Simatupang (2007)

"Industri kreatif yang mengandalkan talenta, ketrampilandan kreativitas yang merupakan elemen dasar setiap individu. Unsur utama industri kreatif adalah kreativitas, keahlian, dan talenta yang berpotensi meningkatkan kesejahteraan melalui kesejahteraan melalui penawaran kreasi intelektual."

c. $\quad$ Menurut UK DCMS Task Force (1998:4)

"Industri kreatif merupakan industri yang berasal dari kreativitas individu, ketrampilan, dan bakat yang secara potensial menciptakan kekayaan, dan lapangan pekerjaan melalui eksploitasi dan pembangkitan kekayaan intelektual dan daya cipta individu."("Creatives Industries as those which have their origin in individual creativity,skill and talent, ad which have a potential for wealth and job creation through the generation and exploitation of intellectual property and content")

\section{d. Menurut UNCTAD dan UNDP dalam Creative Economy Report (2008:4)}

"Industri kreatif dapat didefinisikan sebagai siklus kreasi, produksi, serta distribusi barang dan jasa yang menggunakan kreativitas dan modal intelektual sebagai input utama. Industri kreatif terdiri dari seperangkat pengetahuan berbasis aktivitas yang menghasilkan barang-barang riil dan intelektual nonriil atau jasajasa artistik yang memiliki kandungan kreatif tersusun dari suatu bidang yang heterogen yang saling mempengaruhi dari kegiatan-kegiatan kreatif yang bervariasi, yang tersusun dari seni dan kerajinan tradisional, penerbitan, musik, visual dan pembentukan seni sampai dengan penggunaan teknologi yang intensif 
dan jasa-jasa yang berbasis kelompok, seperti fil, televisi, dan siaran radio, serta media baru dan desain."

\section{Dasar Ekonomi Kreatif}

a. Kreativitas (Creativity)

Dapat dijabarkan sebagai suatu kapasitas atau kemampuan untuk menghasilkan atau menciptakan sesuatu yang unik, fresh, dan dapat diterima umum. Bisa juga menghasilkan ide baru atau praktis sebagai solusi dari suatu masalah, atau melakukan sesuatu yang berbeda dari yang sudah ada (thinking out of the box). Seseorang yang memiliki kreativitas dan dapat memaksimalkan kemampuan itu, bisa menciptakan dan menghasilkan sesuatu yang berguna bagi dirinya sendiri beserta orang lain.

b. Inovasi (Innovation)

Suatu transformasi dari ide atau gagasan dengan dasa kreativitas dengan memanfaatkan penemuan yang sudah ada untuk menghasilkan suatu produk ataupun proses yang lebih baik, bernilai tambah, dan bermanfaat. Sebagai contoh inovasi, cobalah melihat beberapa inovasi di video-video youtube.com dengan kata kunci "lifehack". Di video itu diperlihatkan bagaimana suatu produk yang sudah ada, kemudian di-inovasikan dan bisa menghasilkan sesuatu yang bernilai jual lebih tinggi dan lebih bermanfaat.

c. Penemuan (Invention)

Istilah ini lebih menekankan pada menciptakan sesuatu yang belum pernah ada sebelumnya dan dapat diakui sebagai karya yang mempunyai fungsi yang unik atau belum pernah diketahui sebelumnya. Pembuatan aplikasiaplikasi berbasis android juga menjadi salah satu contoh penemuan yang berbasis teknologi dan informasi yang sangat memudahkan manusia dalam melakukan kegiatan sehari-hari (Rochmat Aldy Purnomo, $2016: 8$ ).

Ekonomi kreatif menjadi salah satu konsep untuk pengembangan perekonomian di Indonesia. Yang mana, Indonesia bisa mengembangkan model ide dan talenta dari rakyat untuk dapat menginovasi dan menciptakan suatu hal. Pola pikir kreatif yang sangat diperlukan untuk tetap tumbuh berkembang serta bertahan di masa yang akan datang. Sehingga dapat disimpulkan bahwa untuk menjadi pekerja kreatif tidaklah cukup memiliki bakat pandai menggambar, menari, menyanyi dan menulis cerita. Ia harus memiliki kemampuan mengorganisasikan ide-ide multi disipliner dan juga kemampuan memecahkan masalah dengan cara-cara di luar kebiasaan (Rochmat Aldy Purnomo, 2016 : 11).

Adapun strategi pengembangan ekonomi kreatif yang direncanakan dalam tahun 2015 sampai dengan 2019 yaitu :

1. Meningkatkan ketersediaan sumber daya manusia (SDM) dan bahan baku untuk pengembangan ekonomi kreatif. Sasarannya adalah 1) Meningkatnya kuantitas dan kualitas orang dan tenaga kerja kreatif 2) Tersedianya bahan baku dari sumber daya alam yang berciri khas lokal, berkelanjutan dan ramah lingkungan dari sumber daya alam Indonesia 3) Meningkatnya penggunaan, pengelolaan, dan perlindungan sumber daya budaya yang berkelanjutan

2. Meningkatkan pertumbuhan dan daya saing industri kreatif. Sasarannya adalah 1) Meningkatnya wirausaha kreatif yang berdaya saing secara nasional dan internasional 2) Terciptanya produk dan jasa kreatif Indonesia yang menjadi ikon nasional dan internasional. 
3. Menciptakan lingkungan yang kondusif untuk pengembangan ekonomi kreatif yang berdaya saing global. Sasaranya adalah 1) Terciptanya pembiayaan yang sesuai dan mudah diakses 2) Meningkatnya keragaman karya kreatif dan pangsa pasar ekonomi kreatif 3) Meningkatnya ketersediaan infrastruktur yang mendorong kelancaran produksi, distribusi dan promosi produk kreatif 4) Meningkatnya ketersediaan teknologi tepat guna dan mudah diakses 5) Terciptanya regulasi yang mendukung penciptaan iklim yang kondusif bagi pengembangan ekonomi kreatif 6) Terciptanya regulasi yang mendukung penciptaan iklim yang kondusif bagi pengembangan ekonomi kreatif 7) Terciptanya regulasi yang mendukung penciptaan iklim yang kondusif bagi pengembangan ekonomi kreatif 8) Meningkatnya partisipasi aktif pemangku kepentingan dalam pengembangan ekonomi kreatif 9) Terwujudnya kreativitas sebagai paradigma pembangunan dan dalam kehidupan masyarakat 10) Meningkatnya posisi, kontribusi, kemandirian serta kepemimpinan Indonesia dalam fora internasional 11) Meningkatnya apresiasi kepada orang/karya/ wirausaha/usaha kreatif lokal di dalam dan luar negeri (Rochmat Aldy Purnomo, 2016 : 45).

\section{Pembahasan}

Kegiatan pengabdian ini terselenggara atas kerjasama dengan siswa siswi serta dewan guru SMK 4 Muhammadiyah Palembang. Kegiatan penyuluhan ini merupakan salah satu tahapan penting dari kegiatan pengabdian kepada masyarakat sebagai Tridarma Perguruan Tinggi yang dilaksanakan pada Agustus 2019. Penyuluhan dilakukan di aula SMK 4 Muhammadiyah Palembang. Yang memberi kata sambutan adalah Kepala Sekolah SMK 4 Muhammadiyah Palembang. Sedangkan sebagai narsumber dalam kegiatan ini adalah saya sendiri. Dimana saya adalah dosen ekonomi syariah serta guru di salah satu sekolah di Palembang. Kegiatan berlangsung lancer dengan suasana kenyamanan.

Dalam pelaksanaannya kegiatan penyuluha ini dihadiri oleh siswa siswi SMK 4 Muhammadiyah serta dewan guru. Peserta yang hadir terlihat antusias mendengarkan penyuluhan yang disampaikan, hal ini tampak dari banyaknya ssiwa siswi yang bertanya tentang bagaimana cara mengembangkan ekonomi kreatif pada sekolah mereka.

Kegiatan penyuluhan ini dilakukan dengan metode ceramah, Tanya jawab serta memberikan arahan kepada siswa untuk mampu mengembangkan ekonomi kreatif seiring dengan berkembangnya UMKM yg ada. seperti memberikan contoh ekonomi kreatif pada sekolah lain, pemutaran film-film ekonomi kreatif. Hal ini bertujuan untuk menumbuhkan kreativitas pada anak.

Potensi siswa siswi SMK Muhammadiyah Palembang sangat beragam dan prospek dikembangkan untuk geliat ekonomi kreatif masyarakat. Seperti mengembangkan kreativitas pembuatan olahan makanan, membuat buket bunga, membuat karya seni lukis. Di sini memiliki tempat yang sangat menarik untuk dikembangkan sebagai upaya peningkatan kesejahteraan. Oleh karena itu materi yang disampaikan sesuai dengan potensi siswa siswi yang ada pada SMK 4 Muhammadiyah Palembang. Materi penyuluhan antara lain mengenai pemahaman apa yang dimaksud dengan ekonomi mreatif, apa itu kreatifitas, bagaimana membuat buket bunga, membuat olahan makanan dan lain-lain. Selain dengan metode ceramah materi juga disampaikan dengan pemutaran video film proes 
pembuatan produk olahan kreatif tersebut. Sehingga siswa siswi lebih cepat memahaminya dan tertarik mengikuti penyuluhan ini.

Pelaksanaan penyuluhan yang diberikan kepada masyarakat sudah merupakan langkah tepat untuk memotivasi selera usaha siswa siswi. Adanya hubungan peranan penyuluhan terhadap peningkatan jumlah siswa yang membuat kerajinan untuk siap dipasarkan. Melalui penyuluhan ini siswa mendapatkan informasi dan wawasan sehingga siswa memahami secara mendalam tentang ekonomi kreatif serta manfaatnya bagi peningkatan jumlah kerajinan pada anak.

Keberhasilan penyuluhan yang ditujukan dengan diterimanya ide baru berlanjut sampai digunakannya ide baru oleh para siswa berlangsung dalam system penyuluhan yang di dalamnya ada beberapa fungsi yang dapat saling mempengaruhi yaitu : 1) fungsi penelitian, 2) fungsi pengaturan 3) fungsi pelayanan 4) fungsi penyuluhan. Beradasarkan fungsi tersebut kegiatan ini memiliki fungsi penyuluhan tampak dari aktivitas siswa SMK Muhammadiyah Palembang, dengan mudah menerima pengetahuan baru dan berkeinginan mengimplementasikannya. Namunterus bias untuk memperoleh hasil yang lebih maksimal hal yang dapat dilakukan adalah diperlukan kegiatan lanjutan yang bersifat pendampingan masyarakat sehingga mereka bisa terus menekuni usaha yang akan dibuat.

Hambatan yang ditemui pada saat penyuluhan adalah menyesuaikan jadwal siswa dengan jadwal kegiatan mengajar. Selain itu masih banyaknya siswa yang belum mngetahui bahwa kegiatan-kegiatan yang sebelumnya mereka lakukan adalah bagian dari ekonomi kreatif yang nantinya dapat memberikan nilai manfaat bagi mereka dan masyarakat sekitar. Seluruh siswa yang menerima penyuluhan berharap aka nada keberlanjutan kegiatan ini dengan penyuluhan-penyuluhan materi lainnya serta adanya pembinaan.

\section{Dokumentasi Kegiatan PKM}

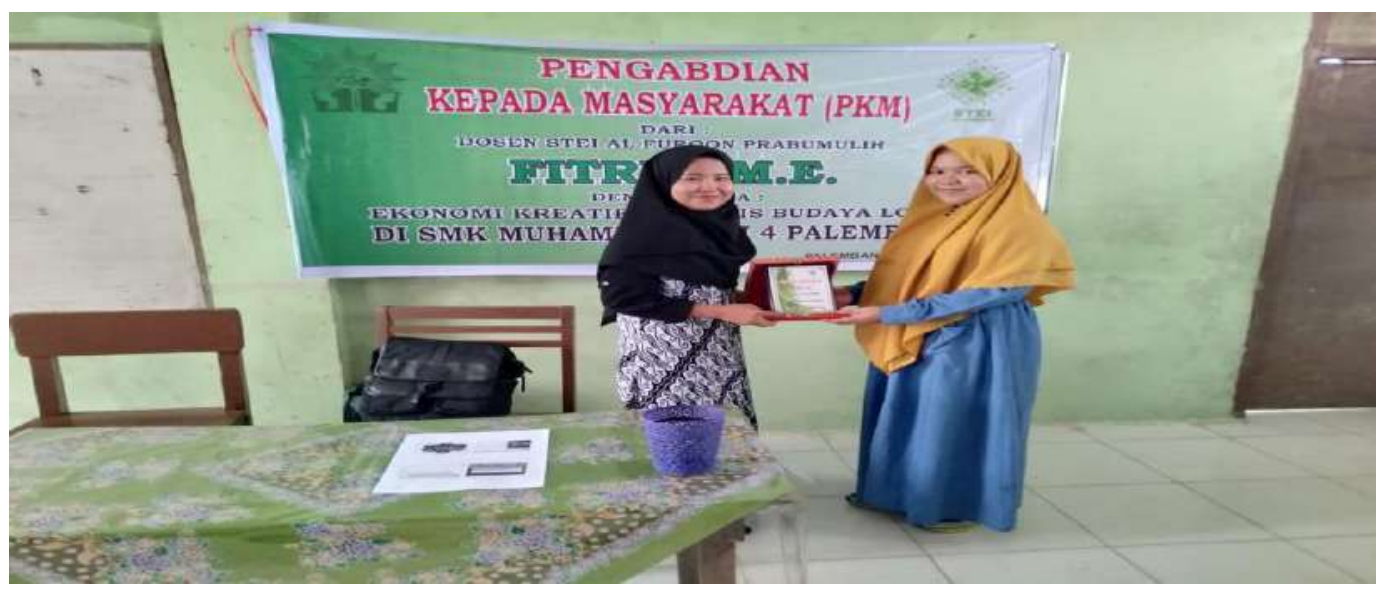



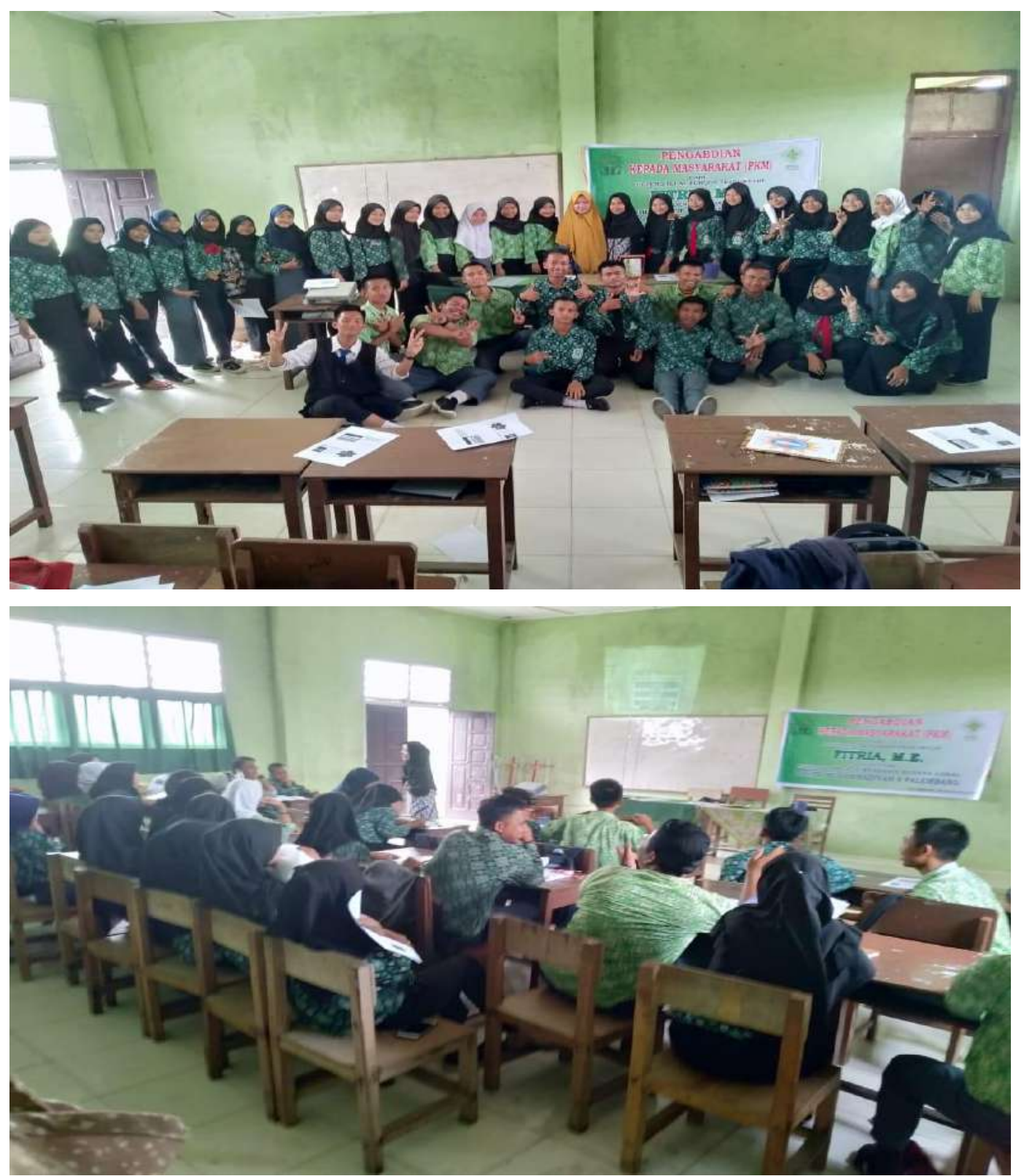

\section{Simpulan}

Kegiatan penyuluhan untuk penguatan ekonomi kreatif berbasis budaya di SMK Muhammadiyah 4 Palembang memberi manfaat bagi siswa. Ini tampak dari antusiasnya para siswa dalam tanya jawab dan termotivasi mengembangkan kreatifitas usahanya. Sehingga kegiatan ini perlu dilakukan secara berkelanjutan. 


\section{Daftar Pustaka}

Departemen Perdagangan Republik Indonesia. (2009). Pengembangan Ekonomi Kreatif Indonesia 2010- 2014. Jakarta: Departemen Perdagangan.

http://prinnovationhub.com/wp-content/uploads/2018/08/creative-economysynthesis_201305.pdf

Http://www.slideshare.net/togar/cetak-biru-industri-kreatif-jabar

https://unctad.org/en/docs/ditc20082cer_en.pdf

https://www.kemendag.go.id/id

Rochmat Adly Purnomo, (2016). Ekonomi Kreatif Pilar Pembangunan Indonesia Banyumas: Nulisbuku.com.

Simatupang, M.T. (2008). Industri Kreatif untuk Kesejahteraan Bangsa. ITB Bandung: Inkubator Industri dan Bisnis.

Simatupang, Togar.( 2007). Ekonomi Kreatif: Menuju Era Kompetisi dan Persaingan Usaha Ekonomi Gelombang IV. Institut Teknologi Bandung.

UNDP-UNCTAD, 2008. Creative Economy Report, United Nations, AS. 